\author{
Zbigniew Zioło \\ Uniwersytet Pedagogiczny \\ im. Komisji Edukacji Narodowej \\ w Krakowie
}

\title{
Rola przedsiębiorczości $w$ warunkach nasilających się procesów globalizacji
}

Nasilające się procesy globalizacji należy traktować jako obiektywne, gdyż kształtujące się pod wpływem rozwoju cywilizacyjnego i związanego z nim postępującego procesu koncentracji kapitału. Wyrazem tego jest powstawanie coraz potężniejszych korporacji, które dzięki coraz nowocześniejszym i bardziej konkurencyjnym produktom, usługom i organizacjom obejmują zasięgiem oddziaływania coraz rozleglejsze rynki, ograniczając równocześnie działalność mniej konkurencyjnych podmiotów lub wchłaniając je do swojej struktury organizacyjnej w drodze przejęć, fuzji, zakupu i in. W konsekwencji postępujący proces koncentracji kapitału w zasadniczym stopniu wpływa na kształtowanie się ponadnarodowych korporacji, które poprzez inwestycje w zakresie działalności produkcyjnej, usługowej i finansowej systematycznie wzmacniają swoją pozycję w przestrzeni światowej ${ }^{1}$. Dokonuje się to także w wyniku lokowania oddziałów na terenie coraz to innych krajów, co przekłada się na zwiększenie zasięgu wpływów o nowe obszary rynkowe ${ }^{2}$. Ponadnarodowe firmy mogą też stwarzać możliwości dla rozwoju małych i średnich przedsiębiorstw dzięki kształtowaniu określonych powiązań kooperacyjnych czy rozwijaniu działalności usługowej. Przyczynia się to do zwiększania strumieni finansowych płynących do gospodarstw domowych i zwiększania zapotrzebowania rynku na oferowane produkty oraz usługi. Procesy globalizacji prowadzą również do pogłębiania już istniejących rynków i obserwowania rynków potencjalnych, które mogą być atrakcyjne wraz ze zwiększaniem się zasobów finansowych mieszkającej na ich terenach ludności.

Wydaje się, że precyzyjniejsze poznanie złożonych mechanizmów procesów globalizacji pozwoli na określenie możliwości wykorzystania ich wpływu dla aktywizacji działań i postaw przedsiębiorczych społeczności układów lokalnych i regionalnych, co powinno prowadzić do ich rozwoju ekonomicznego, społecznego i kulturowego. Stąd w niniejszej pracy podjęto problematykę kształtowania przedsiębiorczości w warunkach nasilających się procesów globalizacji. Problematyka ta jest kontynuacją wcześniejszych rozważań prezentowanych w kolejnych tomach serii „Przedsiębiorczość - Edukacja”, poświęconych roli przedsiębiorczości w: kształtowaniu społeczeństwa informacyjnego, gospodarce opartej na wiedzy, aktywizacji gospodarczej, podnoszeniu konkurencyjności oraz warunkach integracji europejskiej (Zioło, Rachwał 2005, 2006, 2007, 2008, 2009, 2010).

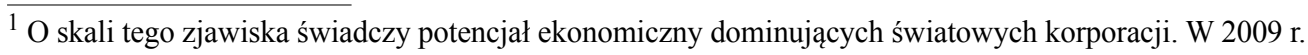
wartość sprzedaży największej z nich, Wal-Mart Stores, wyniosła 408,21 mld USD („Forbes Globar 2000” z 2010 r.), podczas gdy wartość PKB Polski wynosiła 430,6 mld USD.

${ }^{2}$ Na przykład koncern Toyota ma 61 zakładów zlokalizowanych na terenie 26 krajów, w tym w: Japonii (15 zakładów), Chin (13), Malezji i Tajlandii (po trzy), Kanadzie, Stanach Zjednoczonych, Filipinach, Wielkiej Brytanii oraz Polsce (po dwa).
} 


\section{Przesłanki rozwoju przedsiębiorczości}

Zarysowane procesy tworzą zagęszczające się sieci powiązań politycznych, ekonomicznych, społecznych i kulturowych, które wywierają znaczący wpływ na wzrost działalności gospodarczej oraz przyczyniają się do rozwoju przedsiębiorczości.

Ważną rolę w rozwoju przedsiębiorczości odgrywają relacje polityczne, przejawiające się w celowo tworzonych uwarunkowaniach w zakresie kreowania korzystnych instrumentów dla stopniowego nasilania powiązań między poszczególnymi krajami. Przekładają się one na utrwalanie już istniejących lub kreowanie nowych, ale najczęściej korzystniejszych możliwości powiązań gospodarczych podmiotów gospodarczych oraz instytucji. Mogą także tworzyć nowe bariery ograniczające rozwój wzajemnej współpracy ${ }^{3}$.

Relacje ekonomiczne wynikają najczęściej z: odpowiednich zasobów surowcowych, uwarunkowań rynkowych, jakości przestrzeni społeczno-gospodarczej, kulturowej i przyrodniczej. Pozwalają one na rozwój istniejącej działalności produkcyjno-usługowej oraz na wykorzystywanie nowych lokalizacji. Tworzy się w ten sposób podstawa do rozwijania powiązań w zakresie przepływu kapitału w formie bezpośrednich inwestycji zagranicznych, rynków zbytu dla oferowanych produktów, możliwości rozwijania powiązań kooperacyjnych lokalnych podmiotów gospodarczych, rozwijania źródeł zaopatrzenia surowcowego, modernizacji rynku pracy, powiązań finansowych i in. (Bojar 2008, Domański 2001)

Relacje społeczne wpływają na: pobudzanie, hamowanie przepływu lub wykorzystywanie odpowiednio przygotowanych miejscowych zasobów pracy przez nowo lokowane oddziały produkcyjno-usługowe, rozwijanie działalności edukacyjnej i podnoszenie poziomu kwalifikacji zawodowych pracowników, co w konsekwencji prowadzi do wzrostu dochodów finansowych gospodarstw domowych i układów samorządowych (Zioło 1978).

Z kolei relacje kulturowe wpływają na kształtowanie jakości zasobów pracy, formy zarządzania i tworzenie korzystnych uwarunkowań dla otoczenia biznesu. Umożliwiają stworzenie nowej kultury organizacji pracy, często zwiększającej efektywność działalności gospodarczej, transmisję produktów kultury (literackiej, muzycznej, malarskiej, produktów kultury masowej), a także wzorców zachowań i tolerancji w stosunku do osób kształtowanych na odmiennych zasadach kultury duchowej (religijnych, światopoglądowych, prądów filozoficznych i in.). Wpływają również na aspiracje i plany życiowe młodzieży, które nawiązują do zmieniających się uwarunkowań rozwoju (Turczyn-Zioło 1979). Rozwijając działalność gospodarczą, musimy zatem poznać i odpowiednio wykorzystać relacje kulturowe dla podniesienia konkurencyjności wytwarzanych produktów lub oferowanych usług.

Lokalizacja nowego podmiotu gospodarczego w różnym stopniu i często w odmiennym zakresie oddziałuje na poszczególne elementy przestrzeni geograficznej. Kształtujące się procesy przemian dokonujące się w wyniku postępującego rozwoju cywilizacyjnego nakładają się bowiem na zróżnicowane pod względem rozwoju różnej skali układy przestrzenne. Przyrodnicze, gospodarcze, społeczne i kulturowe zróżnicowanie przestrzeni światowej często w odmiennym stopniu umożliwia wykorzystanie reguł rozwoju i stwarzania korzystnych uwarunkowań dla przyjmowania oraz wchłaniania pojawiających się innowacji.

Procesy generowane w skali globalnej w różnym stopniu oddziałują na układy światowe, poszczególnych kontynentów, krajów, regionów czy układy lokalne, które odznaczają się zróżnicowanym poziomem rozwoju i w określonym stopniu umożliwiają bądź hamują rozwój

\footnotetext{
3 Przykładem mogą być ostatnio podjęte decyzje rządu chińskiego o ograniczeniu dostaw do Stanów Zjednoczonych, Europy Zachodniej i Japonii metali rzadkich, niezbędnych do produkcji wyrobów ht czy trudności w negocjacjach zaopatrzenia Polski w ropę i gaz.
} 
przedsiębiorczości. W skali światowej podejmowane są działania prowadzące do zaspokojenia uniwersalnych potrzeb społecznych, takich jak wdrażanie do produkcji i usług nowych narzędzi pracy (komputery, telefony komórkowe, Internet, środki transportu), potrzeba bezpieczeństwa, rozwijanie społecznego uznawania i samorealizacji przedsiębiorstw czy podnoszenia jakości instytucji. Podstawowe znaczenia w tym zakresie mają obszary pełniące funkcję światowych biegunów wzrostu (Stany Zjednoczone, Japonia, Unia Europejska) i ostatnio intensywnie rozwijające się (Chiny, Indie, Rosja, Brazylia), które dzięki innowacjom stopniowo obejmują swoim zasięgiem coraz rozleglejszą przestrzeń światową.

Rozwój poszczególnych kontynentów związany jest z odmiennymi warunkami przyrodniczymi i występującymi zasobami surowcowymi, dominującymi wzorcami kulturowymi, które wywodzą się z określonych zasad i tradycji, wyznawanych religii oraz dziedzictwa kulturowego, a także przyjmowanymi systemami zarządzania gospodarką.

Państwa suwerenne kształtują się nie tylko według własnych reguł, ale wraz z nasilającymi się powiązaniami ekonomicznymi, społecznymi i kulturowymi stopniowo przyjmują też zasady globalnego rozwoju, dostosowując stopniowo swoje uwarunkowania instytucjonalne do nowych reguł rozwoju (np. kształtowanie Unii Europejskiej). Procesy integracji w pewnym stopniu są utrudnione początkowo przez specyficzne wewnętrzne bariery ustrojowo-polityczne, jakość oraz rozmiary zasobów intelektualnych, z których wynikają zasoby kapitału ludzkiego i kapitału społecznego (Kamińska, Heffner 2010).

Do zarządzenia tymi złożonymi procesami techniczno-ekonomicznymi i społecznymi, zarówno w poszczególnych przedsiębiorstwach lub instytucjach, jak i krajowych, regionalnych czy lokalnych układach przestrzennych, potrzebni są odpowiednio przygotowani ludzie. Osoby realizujące swoje plany życiowe wynikające $\mathrm{z}$ wykształconych uprzednio aspiracji, które powinny być wcześniej podbudowywane $\mathrm{w}$ wyniku działalności edukacyjnej, a następnie rozwijane w drodze samokształcenia i zdobywania doświadczenia zawodowego w zakresie lokowania i kierowania coraz bardziej złożonymi strukturami przedsiębiorstw produkcyjnych, usługowych, produkcyjno-usługowych czy instytucji. Duże znaczenie dla rozwoju przedsiębiorczości mają także indywidualne cechy jednostek, kształtowane początkowo przez rodzinę i sytuację układu lokalnego, a w miarę zwiększenia powiązań społeczno-ekonomicznych również przez otoczenie krajowe i międzynarodowe. Brak odpowiednio przygotowanych ludzi osłabia możliwości wykorzystania reguł współczesnego rozwoju dla pobudzania wzrostu gospodarczego.

Wzrost gospodarczy, nasilające się procesy globalizacji i związane z nimi procesy integracji europejskiej są szczególnym wyzwaniem dla kształtowania cech osobowych poszczególnych jednostek ludzkich, przedsiębiorstw oraz społeczności lokalnych, regionalnych i krajowych. Bardzo ważne jest także określenie, w jakim stopniu będą one przydatne do wykorzystania reguł ekonomicznych dla rozwoju gospodarczego, społecznego i kulturowego oraz podnoszenia pozycji konkurencyjnej związanych z nimi układów przestrzennych. Podstawową rolę w tym zakresie odgrywa wybór określonego typu działalności gospodarczej, który wynika z poznania uwarunkowań rozwoju przedsiębiorczości, funkcji produkcyjno-usługowych istniejących podmiotów gospodarczych, $w$ tym podmiotów osób fizycznych oraz warunków otoczenia niezbędnych dla prowadzenia planowanej działalności gospodarczej.

\section{Typy działalności gospodarczej}

Procesy dotyczące działalności gospodarczej bardzo silnie nawiązują do procesu koncentracji kapitału prowadzącego do powstawania coraz większych korporacji i obejmują swoim zasięgiem rynek światowy. Firmy międzynarodowe o dużym potencjale techniczno-ekonomicznym są 
w stanie przeznaczyć znaczne środki na prace badawczo-rozwojowe ${ }^{4}$, lepszą organizację i modernizację procesów produkcyjnych, dokształcanie i doskonalenie zawodowe pracowników, co umożliwia im wprowadzanie na rynek coraz bardziej konkurencyjnych produktów oraz zwiększanie przychodów i zysków z działalności gospodarczej (ryc. 1).

Ryc. 1. Typy działalności gospodarczej

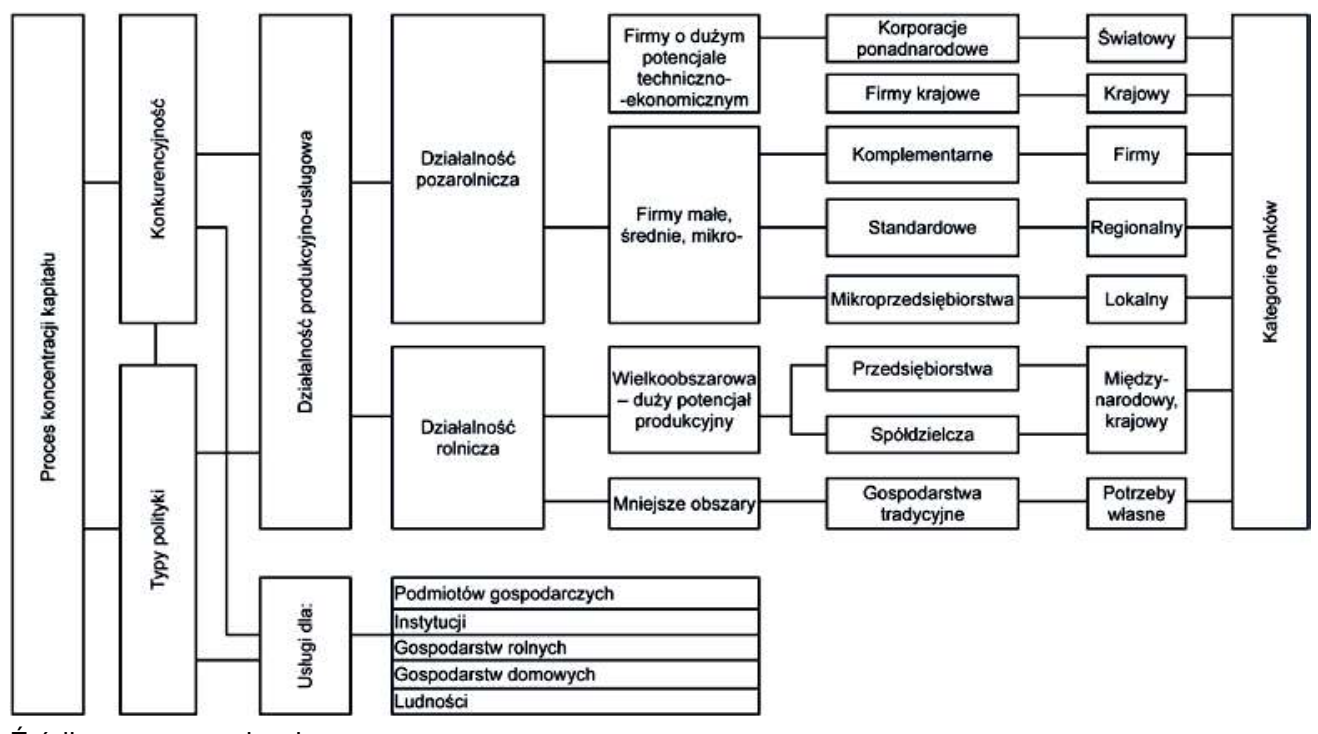

Źródło: opracowanie własne.

W przestrzeni światowej, krajowej czy regionalnej działania te uruchamiają procesy konkurencyjności rynkowej. W wyniku ich nasilania poszczególne przedsiębiorstwa mogą zachowywać się jako elementy:

- zanikłe (które nie sprostały potrzebom rynku i upadły),

- zanikające (których działalność systematycznie się osłabia i prowadzi do upadłości),

- stagnujące (utrzymujące dotychczasową pozycje na rynku),

- rozwijające się (które w wyniku rosnącej pozycji konkurencyjnej rozwijają swoją produkcję i pogłębiają lub zdobywają nowe rynki),

- nowo pojawiające się (które utworzono w wyniku pojawiających się nisz rynkowych i podejmują produkcję nowoczesnych wyrobów).

Proces ten może być wpierany przez odpowiednią politykę ekonomiczną państwa, która może stwarzać bardziej lub mniej korzystne instrumenty pośredniego i bezpośredniego oddziaływania dla rozwoju podmiotów gospodarczych.

Podmioty gospodarcze podejmują określoną działalność gospodarczą w zależności od nisz rynkowych, zasobów kapitałowych i kwalifikacji pracowniczych. Działalność produkcyjna, usługowa czy produkcyjno-usługowa może być wykonywania dla potrzeb przedsiębiorstw prowadzących działalność pozarolniczą lub rolniczą, natomiast działalność usługowa odnosi się zwykle do usług na rzecz podmiotów gospodarczych i instytucji (np. oświatowych, administracyjnych, finansowych, zdrowotnych), gospodarstw rolnych (najczęściej towarowych),

${ }^{4}$ W 2009 r. nakłady na badania i rozwój firmy Toyota (Japonia) wynosiły 6,8 mld USD, Roche (Szwajcaria) - 6,4 mld, Microsoft (USA) - 6,1 mld, Volkswagen (Niemcy) - 5,8 mld, Pfizer (USA) - 5,4 mld. 
gospodarstw domowych (naprawy różnego typu sprzętu, prace remontowe i in.) oraz na potrzeby ludności (działalność handlowa, hotelowa, turystyczna, oświatowa, kulturalna i in.).

Działalność pozarolniczą mogą prowadzić firmy o dużym potencjale techniczno-ekonomicznym, które reprezentują korporacje ponadnarodowe pracujące na potrzeby rynku światowego lub firmy krajowe, pracujące na potrzeby rynku krajowego ${ }^{5}$.

Firmy małe, średnie i mikrofirmy wykazują różnego typu powiązania i spełniają różne funkcje. Reprezentują je podmioty gospodarcze o funkcjach komplementarnych, które pracują na potrzeby najczęściej dużych korporacji. W wyniku powiązań kooperacyjnych dostarczają im różne podzespoły, części zamienne, wykonują prace remontowe itp.

Firmy standardowe pracują głównie na potrzeby regionalne. Wpływają na podnoszenie jakości poszczególnych sektorów, przyczyniając się w ten sposób do unowocześnianie struktur społeczno-gospodarczych i podnoszenia ich konkurencyjności.

Głównym celem mikroprzedsiębiorstw jest zaspakajanie potrzeb rynku lokalnego i ponadlokalnego. Rozwój ich działalności zależy w znacznym stopniu od zasobów finansowych ludności. Wzrost zasobów finansowych wpływa na większe zapotrzebowanie na ich usługi, natomiast spadek zasobów finansowych w znacznym stopniu ogranicza możliwości rozwoju i często prowadzi do zaniku działalności.

Odmienne potrzeby rynkowe stwarza działalność rolnicza. Generalnie nawiązuje ona do prowadzenia upraw zbożowych, hodowli i zaspakajania potrzeb remontowo-budowlanych (maszyn, urządzeń i gospodarstw). Odmienne możliwości rozwoju przedsiębiorczości dają wielkoobszarowe gospodarstwa towarowe, inne - gospodarstwa średnie produkujące częściowo na potrzeby rynku i potrzeby własne, a jeszcze inne - gospodarstwa małe, pracujące przeważnie na własne potrzeby konsumpcyjne.

Oznacza to, że w dążeniach do rozwoju przedsiębiorczości należy dokonać bardzo precyzyjnej oceny możliwości chłonności rynku na oferowane produkty lub usługi. Bardziej stabilny rozwój działalności produkcyjnej mają podmioty o wykształconych powiązaniach funkcjonalnych z korporacjami światowymi i krajowymi. Korporacje te stworzyły własne systemy rynkowe i w mniejszym stopniu podatne są na sezonowe wahania. Mniej stabilny jest los przedsiębiorstw pracujących na potrzeby lokalne, zwłaszcza na potrzeby ludności, które w zasadniczym stopniu związane są z rozmiarami zasilenia finansowego gospodarstw domowych. Wahania w zakresie wielkości dochodów gospodarstw domowych wpływają na zachowanie się podmiotów gospodarczych, zwłaszcza usługowych. W miarę zwiększania się zasobów finansowych gospodarstw domowych ich popyt na oferowane produkty i usługi wzrasta, a w miarę ich kurczenia się - maleje.

\section{Uwarunkowania rozwoju przedsiębiorczości}

Rozwój przedsiębiorczości dokonuje się w określonych uwarunkowaniach. Znaczący wpływ wywierają tu: przyjmowane reguły rozwoju, typy polityki społeczno-gospodarczej, skala przestrzeni oraz typy firm (tab. 1).

Regułami makroekonomicznego rozwoju rządzi się państwo, nawiązując także do przyjętych dokumentów lub umów międzynarodowych (np. Unii Europejskiej). Reguły mezoekonomiczne

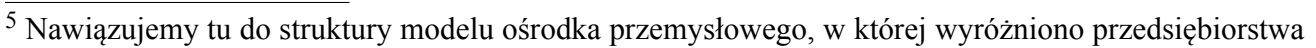
o funkcjach egzogenicznych: podstawowe (wiodące) i komplementarne (standardowe) oraz endogenicznych (o funkcjach lokalnych), a także ich powiązania sieciowe w zakresie relacji produkcyjnych (Zioło 1988).
} 
wynikają z uwarunkowań regionalnych. Wykorzystuje się je dla pobudzania i rozwijania gospodarki układów przestrzennych lub określonych sektorów. Regułami mikroekonomicznymi kierują się poszczególne podmioty gospodarcze, których podstawowym celem jest maksymalizacja zysku często poprzez obniżanie kosztów produkcji.

Ważną rolę w zakresie kreowania rozwoju gospodarczego odgrywają typy polityki gospodarczej, w których przyjmuje się określone proporcje udziału mechanizmów rynkowych, oraz wpływ państwa na realizację zakładanych kierunków rozwoju gospodarczego, społecznego i kulturowego. Generalnie nawiązują one do podstawowego prawa ekonomicznego traktującego o tym, że potrzeby społeczne są nieograniczone, natomiast możliwości ich zaspokajania są ograniczone. Bardzo ważnym działaniem w tym zakresie pozostaje przeznaczanie określonych środków na cele konsumpcji i akumulacji oraz kreowanie odpowiednich instrumentów pośredniego lub bezpośredniego oddziaływania na kierunki rozwoju ${ }^{6}$. Krańcowe typy polityki mogą wahać się od polityki rynkowej, w której przemiany społeczno-gospodarcze regulują mechanizmy rynkowe z minimalnym udziałem państwa, do polityki centralnego sterowania, w której decydujący wpływ na kierunki rozwoju ma państwo. Między tymi krańcowymi typami występuje typ polityki mieszanej oraz interwencjonizm państwowy, gdzie reguły rynkowe i rola państwa występują w pewnych proporcjach oraz w różnym stopniu odnoszą się do określonych zakresów działalności gospodarczej czy sektorów gospodarki.

Zarówno efekty reguł rozwoju, jak i typy polityki są bardzo zróżnicowane w zależności od położenia w przestrzeni geograficznej: w przestrzeni światowej, Unii Europejskiej, Europie Wschodniej, poszczególnych krajach, regionach, a nawet układach lokalnych. Wynika to z tezy, że reguły rozwoju ekonomicznego, społecznego i kulturowego oraz typy polityki mają charakter aprzestrzenny, a zróżnicowane uwarunkowania przestrzenne stwarzają często odmienne możliwości ich działania i - w konsekwencji - dają często odmienne rezultaty ${ }^{7}$. Stąd np. zróżnicowane warunki i poziom rozwoju krajowych struktur regionalnych wymagają stosowania różnych instrumentów dla pobudzania ich rozwoju gospodarczego.

Rozwój przedsiębiorczości odnosi się do podmiotów gospodarczych odznaczających się różną wielkością potencjału ekonomicznego oraz funkcjami spełniającymi w przestrzeni gospodarczej. Wśród nich można wyróżnić przedsiębiorstwa o funkcjach krajowych, komplementarnych, standardowych, mikroprzedsiębiorstwa o funkcjach lokalnych (Zioło 1988 ).

Funkcje globalne i międzynarodowe spełniają duże korporacje obejmujące swoim zasięgiem oddziaływania na przestrzeń światową. Działania te przejawiają się głównie w zakresie powiązań rynkowych, inwestycyjnych, kapitałowych, organizacyjnych i in., które dokonują się najczęściej między podmiotami występującymi na obszarze światowych metropolii. Korporacje te są więc głównymi czynnikami integrującymi gospodarkę światową, intensyfikując w ten sposób działania procesów globalizacji (Zioło, Makieła 2003; Zioło 2006; Gierańczyk, Stańczyk 2003; Wajda 2003).

\footnotetext{
${ }^{6}$ Regulują to odpowiednie ustawy umożliwiające rozwój określonych typów działalności gospodarczej na danym obszarze, np. w okresie międzywojennym budowa Gdyni, Centralnego Okręgu Przemysłowego, a współcześnie - tworzenie specjalnych stref ekonomicznych (Kitowski 2009, Kudełko 2006, Zioło 1984).

${ }^{7}$ Obszary będące na różnym poziomie rozwoju gospodarczego czy odznaczające się odmiennymi uwarunkowaniami przyrodniczymi w różnym stopniu przygotowane są na wdrażanie reguł rozwoju społeczeństwa fazy informacyjnej. Inne typy polityki, np. w Korei Południowej i Północnej, dają różne efekty rozwoju społeczno-gospodarczego.
} 
Funkcje krajowe spełniają przedsiębiorstwa pracujące na wewnętrzne potrzeby gospodarki danego państwa. W przestrzeni krajowej nasilają one powiązania międzyregionalne, zwłaszcza między obszarami metropolitalnymi. Obejmują one także powiązania w zakresie organizacji zachodzące między siedzibami zarządów a oddziałami (Śleszyński 2007).

Funkcje komplementarne spełnią firmy pracujące na potrzeby korporacji międzynarodowych i krajowych. Dostarczają one określone produkty wytwarzane w ramach powiązań kooperacyjnych, zaopatrują w maszyny i urządzenia, programy informatyczne, surowce lub wykonują specjalistyczne usługi remontowe i budowlano-montażowe.

Podmioty gospodarcze o funkcjach komplementarnych pracują głównie na potrzeby danego układu regionalnego. Potrzeby w tym zakresie związane są ściśle z ich poziomem rozwoju i strukturą społeczno-gospodarczą. Stąd w określonych układach regionalnych podmioty gospodarcze odznaczają się różnym potencjałem oraz strukturą branżową.

Mikroprzedsiębiorstwa pracują przede wszystkim na potrzeby rynku lokalnego, a główny czynnik ich rozwoju to najczęściej zasoby finansowe ludności określające chłonność rynku.

W procesie rozwoju poszczególne typy przedsiębiorstw mogą zmieniać swoje funkcje, przechodząc od funkcji lokalnych, poprzez funkcje standardowe i krajowe, po funkcje światowe. Licznych przykładów dostarczają w tym zakresie rozwijające się firmy informatyczne, które rozpoczynały swoją działalność od niewielkich przedsiębiorstw i w wyniku dalszego rozwoju w ostatnich latach osiągnęły poważne sukcesy i stały się korporacjami o funkcjach światowych (Kilar 2009).

Poszczególne kategorie uwarunkowań rozwoju przedsiębiorczości kształtują się według własnych reguł rozwoju, co przedstawiają relacje występujące na przekątnej tablicy $1 . \mathrm{Na}$ przykład relacje zachodzące między regułami makroekonomicznymi opisuje - $\mathrm{g}^{\mathrm{g}}$, między regułami polityki rynkowej $-\mathrm{x}^{\mathrm{x}}$, obszarami w przestrzeni światowej $-\mathrm{m}^{\mathrm{m}}$, między korporacjami $-\mathrm{h}^{\mathrm{h}}$, między mikroprzedsiębiorstwami $-\mathrm{k}^{\mathrm{k}}$ itp.

Wymienione kategorie uwarunkowań nie występują w odosobnieniu, ale zachodzą między nimi różnego typu relacje aktywne i pasywne. Relacje aktywne określają wpływ danej kategorii uwarunkowań na pozostałe kategorie, które przedstawiają wiersze tablicy, np. wpływ reguł makroekonomicznych $(\mathrm{G})$ na pozostałe elementy uwarunkowań przedstawia wiersz relacji od $\mathrm{g}^{\mathrm{s}}$ po $\mathrm{g}^{\mathrm{k}}$; wpływ korporacji światowych $(\mathrm{H})$ na pozostałe elementy przedstawia wiersz relacji od $h^{\mathrm{g}}$ po $\mathrm{h}^{\mathrm{k}}$. W podobny sposób można określić wpływ poszczególnych elementów uwarunkowań na pozostałe elementy. Relacje pasywne ilustrują kolumny, które przedstawiają wpływ poszczególnych elementów uwarunkowań na daną kategorię, np. wpływ poszczególnych elementów uwarunkowań na przestrzeń Europy Wschodniej przedstawia kolumna relacji od gw po $\mathrm{k}^{\mathrm{w}}$; a wpływ poszczególnych elementów uwarunkowań na przedsiębiorstwa ilustruje wiersz od $\mathrm{g}^{\mathrm{k}}$ po $\mathrm{b}^{\mathrm{k}}$ itp.

Przedstawione kategorie uwarunkowań oraz relacje zachodzące między nimi wskazują na dużą złożoność problematyki funkcjonowania i rozwoju podmiotów gospodarczych oraz instytucji. Dlatego przedsiębiorca, który chce podejmować racjonalne decyzje, powinien się z nimi zapoznać i określić w nich miejsca firmy, którą zarządza lub którą chce założyć.

\section{Ksztaltowanie mikroprzedsiębiorstw}

Przedstawione rozważania wskazują, że także poszczególne mikroprzedsiębiorstwa funkcjonują i kształtują się w bardzo złożonych uwarunkowaniach - na tablicy 1 wewnętrzny proces ich funkcjonowania przedstawia $\mathrm{k}^{\mathrm{k}}$. Jednak i one w swoisty sposób wpływają na poszczególne firmy i oddziałują na różnego typu uwarunkowania. Wpływ poszczególnych podmiotów na poszczególne segmenty uwarunkowań przedstawia wiersz tablicy od $\mathrm{k}^{\mathrm{g}}$ po $\mathrm{k}^{\mathrm{b}}$, 


\begin{tabular}{|c|c|c|c|c|c|c|c|c|c|c|c|c|c|c|c|}
\hline \multirow{5}{*}{ 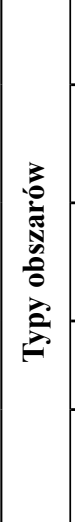 } & 尚 & $\breve{b}_{6}$ & $\dddot{\dddot{n}}_{n}$ & 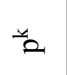 & $\ddot{x}$ & $\ddot{\partial}$ & $\ddot{\vec{z}}$ & $\ddot{\Rightarrow}$ & $\ddot{3}$ & $\because$ & $\stackrel{=}{=}$ & $\ddot{0}$ & $\ddot{\sigma}$ & $\because 0$ & $\ddot{z}$ \\
\hline & 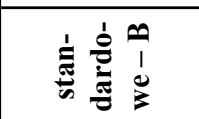 & $\left.{ }^{-\infty}\right)$ & $i_{n}$ & $\stackrel{\circ}{=}$ & $\stackrel{\circ}{x}$ & $\stackrel{P}{>}$ & है & $\stackrel{\circ}{=}$ & $\xi$ & $\mathrm{O}$ & 로 & $\dot{0}$ & $\stackrel{\pi}{\circ}$ & $\stackrel{\circ}{\circ}$ & $\approx$ \\
\hline & 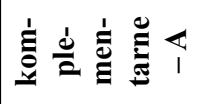 & "5 & is & 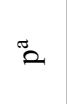 & $\ddot{x}$ & 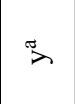 & $\stackrel{\pi}{\sharp}$ & 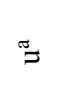 & 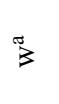 & ฮु & $\stackrel{\nwarrow}{\simeq}$ & ¿ & $\pi$ & مَّ & $\ddot{v}$ \\
\hline & i & ios & is & : & ${ }_{x}$ & $i$ & $\stackrel{\circ}{\sharp}$ & $\stackrel{\circ}{\Rightarrow}$ & 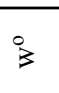 & : & $\stackrel{\circ}{\simeq}$ & $\therefore$ & $\circ$ & مْ & $\stackrel{\circ}{\approx}$ \\
\hline & 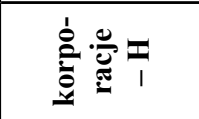 & $F_{-0}$ & $\approx$ & $\approx$ & $\bar{x}$ & $\Rightarrow$ & $\bar{\exists}$ & $\Rightarrow$ & $\overline{3}$ & $=$ & $\exists$ & $=0$ & $\Rightarrow$ & $\approx$ & 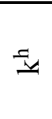 \\
\hline \multirow{4}{*}{ 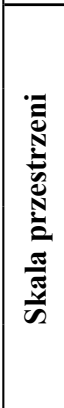 } & ت্تে & is & in & $\stackrel{0}{2}$ & $\dot{u}_{x}$ & i & $\stackrel{\Xi}{\sharp}$ & $\stackrel{\circ}{=}$ & $i$ & ن & $\stackrel{\text { I }}{1}$ & $\because 0$ & $\ddot{\sigma}_{\sigma}$ & م: & $\stackrel{0}{ }$ \\
\hline & 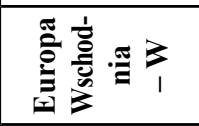 & \%o & $z_{n}$ & 3 & ${ }_{x}^{3}$ & $\stackrel{3}{>}$ & $\stackrel{3}{\sharp}$ & $\exists$ & 3 & $\Xi_{0}$ & 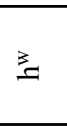 & $3_{0}$ & $z_{\pi}$ & 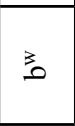 & $\underline{z}$ \\
\hline & | & $z_{0}$ & $\approx_{\infty}$ & 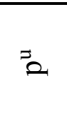 & $z_{x}$ & $\Rightarrow$ & $\bar{\Xi}$ & $\Rightarrow$ & $\overline{3}$ & $\exists$ & $\exists$ & ${ }_{0}$ & $\vec{\sigma}_{\sigma}$ & $\exists$ & 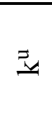 \\
\hline & $\frac{\bar{\pi}}{3} \sum_{1}$ & $\bar{\sigma}_{0}$ & $z_{s}$ & $\Xi_{2}$ & $\nexists_{x}$ & $\equiv$ & $\equiv$ & $\equiv$ & $\overline{3}$ & ઇ & $\Xi$ & $\Xi_{0}$ & $\Xi_{\varpi}$ & $\Xi$ & 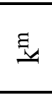 \\
\hline \multirow{2}{*}{ 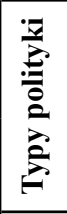 } & 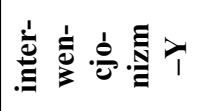 & דo & is & $\hat{\mathrm{z}}$ & 'े & 分 & એै & $\triangleq$ & $\overline{3}$ & $\mathrm{c}$ & $\gtrsim$ & गे & సે & $\hat{3}$ & 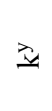 \\
\hline & 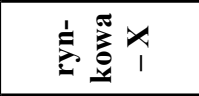 & $x_{00}$ & $x_{i}$ & $\stackrel{*}{\approx}$ & ${ }_{x}^{x}$ & $\ddot{\lambda}$ & $\stackrel{\times}{\text { I }}$ & $\stackrel{x}{\exists}$ & $\hat{z}$ & x & $\stackrel{x}{\hookrightarrow}$ & $x_{0}$ & $x_{\infty}$ & م. & $\ddot{z}$ \\
\hline \multirow{3}{*}{ 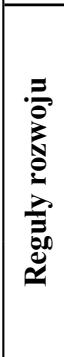 } & 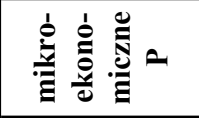 & $\tilde{t}_{0}$ & in & $\approx$ & $\tilde{x}$ & 市 & छี & $\fallingdotseq$ & $\bar{z}$ & \% & $\nexists$ & 8 & $\approx$ & 3 & $\approx$ \\
\hline & 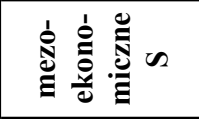 & $w_{00}$ & $\infty_{\infty}$ & $\stackrel{n}{2}$ & $\tilde{x}_{x}$ & 3 & $\stackrel{n}{\Xi}$ & 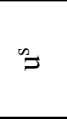 & $\hat{z}$ & so & 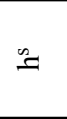 & $" 0$ & 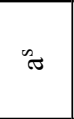 & 0 & $\underline{w}$ \\
\hline & 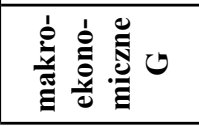 & ${ }^{\circ}$ & $\stackrel{d n}{n}$ & $\stackrel{\infty}{\Omega}$, & $\stackrel{\Delta D}{x}$ & $\stackrel{\text { Do }}{>}$ & $\stackrel{\infty 00}{\sharp}$ & $\stackrel{D D}{=}$ & $\stackrel{o p}{3}$ & Do & $\stackrel{\infty}{\simeq}$ & on & 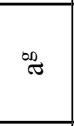 & $\stackrel{\infty}{0}$ & $\stackrel{00}{=}$ \\
\hline \multirow{2}{*}{\multicolumn{2}{|c|}{ 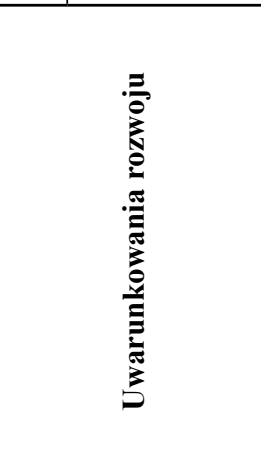 }} & 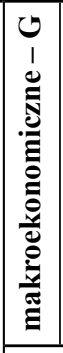 & 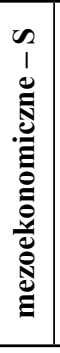 & 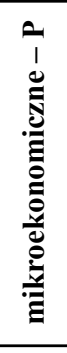 & 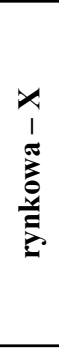 & 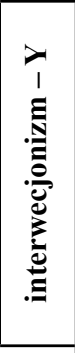 & 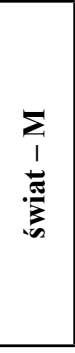 & 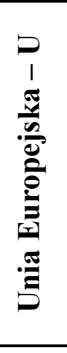 & 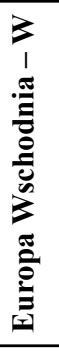 & $\begin{array}{l}0 \\
\frac{1}{\pi} \\
\frac{\pi}{4}\end{array}$ & 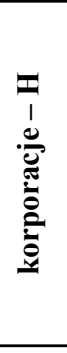 & 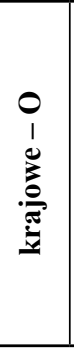 & 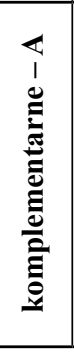 & 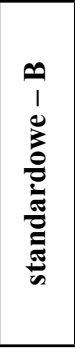 & 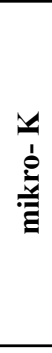 \\
\hline & & \multicolumn{3}{|c|}{ 胥离 } & \multicolumn{2}{|c|}{ 迹 } & \multicolumn{4}{|c|}{ 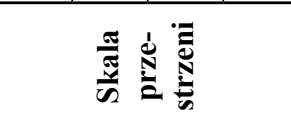 } & \multicolumn{5}{|c|}{$\stackrel{2}{2}$} \\
\hline
\end{tabular}


natomiast wpływ poszczególnych segmentów uwarunkowań na podmiot gospodarczy ilustruje kolumna od $\mathrm{g}^{\mathrm{k}}$ po $\mathrm{b}^{\mathrm{k}}$. Dlatego należy przyjąć, że sukces ekonomiczny tej kategorii podmiotów gospodarczych gwarantuje uprzednio poznanie zmieniających się uwarunkowań oraz wyznaczanie dla nich miejsca wśród różnorodnych kategorii podmiotów gospodarczych.

Mikroprzedsiębiorstwa nie stanowią jednorodnych podmiotów gospodarczych, ale odznaczają się różnymi funkcjami, które spełniają w przestrzeni gospodarczej układów lokalnych i ponadlokalnych. Wynikają one głównie z określonego rodzaju działalności gospodarczej, który umożliwia im kształtowanie odpowiednich powiązań rynkowych. Powiązania te mogą odnosić się do: kooperacji z firmami międzynarodowymi, krajowymi, działalności usługowo-produkcyjnej z innymi mikropodmiotami gospodarczymi, produkcji i usług dla ludności i in. (ryc. 2). Poszczególne typy powiązań wymagają odmiennego zarządzania zgodnie z regułami mikroekonomicznymi oraz dają różne możliwości rozwoju wynikające z zmieniających się uwarunkowań otoczenia.

Ryc. 2. Funkcje produkcyjno-usługowe mikroprzedsiębiorstw (podmiotów gospodarczych osób fizycznych)

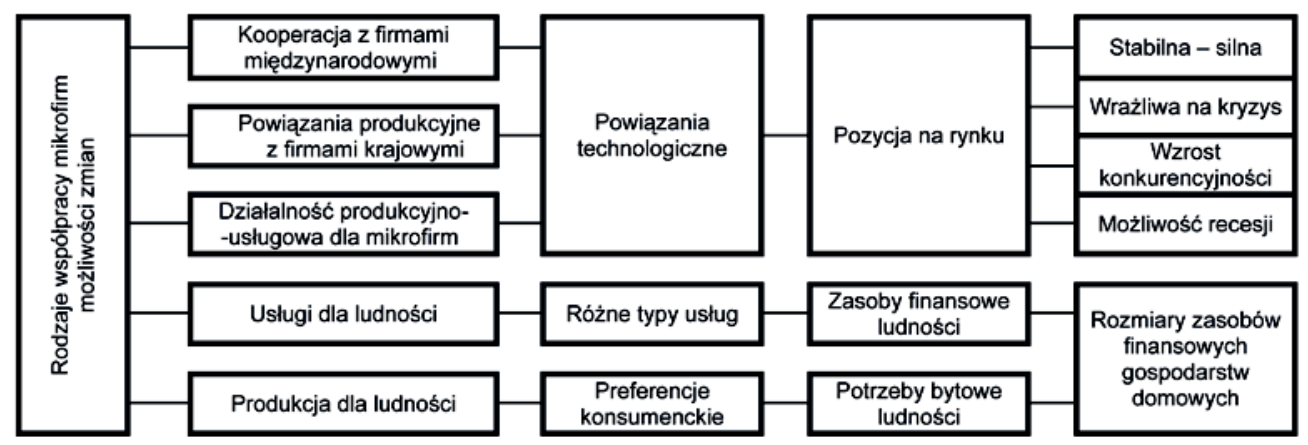

Źródło: opracowanie własne.

Rozwijanie powiązań kooperacyjnych mikroprzedsiębiorstw z korporacjami międzynarodowymi wymaga dbałości o ciągłe doskonalenia procesów wytwarzania oraz zdobywania odpowiednich umiejętności, celem realizacji zamówień i dostarczania właściwych produktów, które następnie wykorzystane są do montowania bardziej złożonych podzespołów. W stosunku do innych podmiotów gospodarczych kształtujące się powiązania technologiczne muszą opierać się na regułach konkurencyjnych zarówno w zakresie jakości dostarczanych produktów czy wykonywanych usług, jak i pod względem oferowanych cen. Współpraca z korporacją umożliwia wdrażanie nowych technologii, zdobywanie kwalifikacji, zapewnia także stabilność działalności oraz ciągły odbiór określonej liczby zamówionych produktów czy usług po ustalonej cenie. Umożliwia to planowanie rozwoju działalności w dłuższym okresie czasu, mniej podatnej na wahającą się koniunkturę rynkową. Podobne relacje, ale mniej trwałe, zachodzą w wyniku powiązań produkcyjno-usługowych z firmami krajowymi, które są podatniejsze na wahania koniunkturalne. Najmniej stabilne możliwości współpracy występują między działalnością produkcyjno-usługową mikroprzedsiębiorstw. Współpraca ta wymaga bowiem dużej elastyczności zmieniającego się rynku oraz ciągłych poszukiwań pojawiających się na nim luk.

Odrębną kategorię mikroprzedsiębiorstw stanowią podmioty wykonujące działalność produkcyjną oraz usługową na potrzeby ludności. Działalność ich nawiązuje do preferencji 
konsumenckich i zapotrzebowania na różnego rodzaju usługi w lokalnych uwarunkowaniach ekonomicznych, społecznych i kulturowych. W zasadniczym stopniu na możliwości rozwoju tego typu podmiotów wpływają zasoby finansowe gospodarstw domowych, które kształtują określone rozmiary rynku lokalnego.

Reasumując, należy przyjąć, że dla rozwoju działalności poszczególnych kategorii mikroprzedsiębiorstw podstawowe znaczenie ma pozycja odbiorców na rynku współpracujących z nimi korporacji międzynarodowych, firm krajowych czy innych mikroprzedsiębiorstw. Najbardziej stabilną sytuacją rynkową odznaczają się zwykle korporacje międzynarodowe. W porównaniu z pozostałymi firmami są one mniej wrażliwe na kryzys i ograniczają możliwość recesji współpracujących z nimi mikrofirm. Wymagają natomiast dbania o wzrost konkurencyjności oferowanych produktów i usług. Firmy krajowe są bardziej wrażliwe na zmieniającą się sytuację rynkową. Wynika to z większych możliwości obniżania ich pozycji konkurencyjnej, co z kolei może prowadzić do recesji. Najmniej stabilne pod tym względem są relacje z mikroprzedsiębiorstwami. Natomiast rozwój działalności mikroprzedsiębiorstw pracujących na potrzeby rynku lokalnego w zasadniczym stopniu związany jest $\mathrm{z}$ tendencjami, które kształtują rozmiary źródeł zasilania finansowania gospodarstw domowych. Wraz z ich zmniejszaniem się maleje popyt na oferowane przez te firmy produkty i usługi, często podejmowane są prace we własnym zakresie (np. gastronomiczne, kulturowe). Zmniejsza się także rynek na potrzeby konsumenckie lub potrzeby są zaspakajane przez tańsze suplementy. Natomiast wzrost zasilania finansowego gospodarstw domowych wpływa na zwiększanie rozmiarów rynku dla podmiotów gospodarczych o funkcjach lokalnych.

\section{Kreowanie zachowań przedsiębiorczych}

Poznanie typów działalności, uwarunkowań rozwoju przedsiębiorczości oraz możliwości rozwoju mikroprzedsiębiorstw, pozwala na kształtowanie cech osobowych przedsiębiorcy oraz otoczenia lokalnego, regionalnego i krajowego. Na wstępie należy przyjąć tezę, że procesy rozwoju podmiotu gospodarczego kreuje przedsiębiorca, opierając się na regułach ekonomicznych, funkcjonujących w zmieniającym się otoczeniu, kształtowanym przez nasilające się procesy rozwoju cywilizacyjnego, a także na zasadach etyki. Wyznaczają one kierunki rozwijania cech osobowych oraz określają umiejętności posługiwania się wiedzą odnoszącą się do zachowań przedsiębiorstw w zmieniającym się otoczeniu (tab. 2).

Kształtowanie cech osobowych przedsiębiorcy zasadza się na wrodzonych zdolnościach i związanych z nimi predyspozycjach. Umożliwiają one wykształcanie aspiracji, które są podstawowym motorem rozwijania działalności przez człowieka. Wpływają one na wybór odpowiedniego kierunku kształcenia oraz dbanie o zdobywanie umiejętności dokształcania i doskonalenia w określonej dziedzinie. Rozwijają one inteligencję człowieka oraz zainteresowania związane z podejmowanymi działaniami.

Cechy te dają podstawę do rozwijania umiejętności stawiania racjonalnych celów oraz wytrwałości w ich realizacji na tle zmieniającego się otoczenia. Dzięki temu kształtuje się silna osobowość, odporna na stres i napotykane niepowodzenia, a także potrafiąca posługiwać się zdobytą wiedzą i współpracować ze środowiskiem wewnętrznym (zespołem współpracowników) i zewnętrznym (ludźmi z otoczenia biznesowego).

Ważną rolę w tym zakresie odgrywa umiejętne wykorzystanie reguł kształtowania procesów technologicznych i ekonomicznych dla lokalizacji czy aktywizacji czynników pobudzania rozwoju firmy na podstawie reguł cyklu życia produktu. 
Tab. 2. Wybrane cechy osobowe przedsiębiorczego człowieka i jego otoczenia

\begin{tabular}{|c|c|}
\hline \multicolumn{2}{|r|}{$\begin{array}{c}\text { Procesy globalizacji kreuje przedsiębiorca, opierając się na regulach ekonomicznych } \\
\text { i zasadach etyki, funkcjonujących w zmieniającym się otoczeniu ksztaltowanym } \\
\text { przez zmieniające się tendencje rozwoju cywilizacyjnego }\end{array}$} \\
\hline \multirow{12}{*}{$\begin{array}{l}\text { Cechy } \\
\text { osobowe }\end{array}$} & wrodzone predyspozycje \\
\hline & aspiracje - podstawowy motor działania człowieka \\
\hline & $\begin{array}{l}\text { wykształcenie i jego aktualizowanie formalne, samokształcenie, doskonalenie } \\
\text { zawodowe }\end{array}$ \\
\hline & rozwijana inteligencja \\
\hline & zainteresowanie działaniami i pracowitość \\
\hline & $\begin{array}{l}\text { umiejętność stawiania celów na podstawie analizy zmieniającego się otoczenia } \\
\text { (wypełnianie luk rynku) }\end{array}$ \\
\hline & wytrwałość i elastyczność w zakresie realizowania celów \\
\hline & $\begin{array}{l}\text { silna osobowość (odporność na stres i niepowodzenia, umiejętność gospodarowania } \\
\text { sukcesem) }\end{array}$ \\
\hline & umiejętność posługiwania się interdyscyplinarną wiedzą \\
\hline & $\begin{array}{l}\text { umiejętność i rzetelność współpracy ze środowiskiem wewnętrznym i otoczeniem } \\
\text { (ograniczanie i niwelowanie konfliktów) }\end{array}$ \\
\hline & $\begin{array}{l}\text { umiejętność wykorzystywania reguł procesu techniczno-ekonomicznego dla } \\
\text { pobudzania rozwoju firmy }\end{array}$ \\
\hline & umiejętność określania faz cyklu koniunkturalnego na dany produkt lub usługę \\
\hline \multirow{7}{*}{$\begin{array}{l}\text { Warunki } \\
\text { otoczenia }\end{array}$} & jakość instytucji edukacyjnych \\
\hline & atrakcyjność obszaru i kultura innowacyjna \\
\hline & inwestycje krajowe i zagraniczne \\
\hline & jakość samorządów \\
\hline & jakość instrumentów pośredniego i bezpośrednio oddziaływania \\
\hline & otoczenie finansowe \\
\hline & jakość polityki społeczno-gospodarczej \\
\hline
\end{tabular}

Źródło: opracowanie własne.

Kształtowanie postaw przedsiębiorczych wymaga przyjaznych sytuacji w otoczeniu lokalnym, regionalnym i krajowym. Przejawia się to w:

- dbaniu o podnoszenie poziomu instytucji edukacyjnych na różnym poziomie kształcenia, dokształcania i doskonalenia zawodowego,

- podnoszeniu atrakcyjności danego obszaru i rozwijania kultury innowacyjnej dla przyciągania endogenicznych czynników rozwoju, głównie w formie inwestycji, napływu kapitału, wykształconej kadry, zintensyfikowanie działalności inwestycji krajowych i zagranicznych,

- przyjaznym stosunku i jakości władz samorządowych do podnoszenia konkurencyjności danego obszaru, generowaniu instrumentów pośredniego i bezpośredniego oddziaływania na rzecz rozwoju gospodarczego, społecznego i kulturowego,

- kształtowaniu sprawnie działającego otoczenia finansowego. 
Odpowiednio przygotowani przedsiębiorcy, członkowie władz samorządowych i racjonalnie zachowujące się społeczeństwo będą pobudzać wszelkie możliwe czynniki rozwoju oraz podnosić jakość lokalnej, regionalnej czy krajowej polityki ekonomicznej i społecznej sprzyjającej rozwojowi gospodarczemu.

Wskazuje to na bardzo złożone procesy kształtowania człowieka przedsiębiorczego. Podstawą w tym zakresie jest edukacja przedsiębiorczości, której celem jest poznanie procesów rozwoju na tle zmieniających się tendencji rozwoju cywilizacyjnego, wdrażanie do umiejętnego posługiwania się wiedzą oraz kształtowanie określonych cech osobowych młodzieży.

W warunkach gospodarki rynkowej kształcenie w tym zakresie jest niezbędne nie tylko dla przyszłych przedsiębiorców, którzy kierować będą różnego rodzaju podmiotami gospodarczymi, ale także dla osób, które w przyszłości podejmować będą zajęcia w wolnych zawodach czy zarządzać gospodarstwem domowym. Wiedza z tego zakresu jest więc potrzebna ludziom sztuki (prezentowanie efektów pracy, zdobywanie dla nich rynku), osobom zakładającym własne kancelarie, lekarzom podejmującym samodzielną działalność związaną z ochroną zdrowia. Przyda się ona też w gospodarstwie domowym, dla którego ważną rzeczą jest dbałość o odpowiednie zasilanie finansowe oraz racjonalny podział uzyskanych środków. Dla skutecznej działalności niezbędna jest podstawowa wiedza z zakresu organizacji, marketingu, konkurencyjnego zachowania, składania ofert itp. Często bowiem dla realizacji swoich zamiarów i podnoszenia efektów działalności trzeba podejmować decyzje związane z miejscem lokalizacji działalności gospodarczej, rynkami, korzystaniem z usług instytucji finansowych lub prawnych oraz współdziałać z instytucjami administracyjnymi i pozarządowymi. Edukacja przedsiębiorczości na poziomie kształcenia ponadpodstawowego daje więc podstawy do kształtowania odpowiednich zachowań umożliwiających odnoszenie życiowego sukcesu na wielu polach działalności człowieka. Nasilające się procesy globalizacji i przechodzenia do fazy społeczeństwa informacyjnego wymagają bowiem odpowiednio przygotowanych ludzi, którzy opanują nowe umiejętności i przyjmą nowe wzorce zachowań niezbędne do swobodnego poruszania się w krajowej, europejskiej i światowej przestrzeni gospodarczej, społecznej i kulturowej.

\section{Literatura}

1. Bojar E., (red.), 2008, Bezpośrednie inwestycje zagraniczne w regionach słabo rozwiniętych, Dom Organizatora, Torun.

2. Borowiec M., 2009, Funkcje wyższych uczelni w procesie ksztaltowania Rzeszowskiego Obszaru Metropolitalnego [w:] Potencjalne metropolie ze szczególnym uwzględnieniem Polski wschodniej, Z. Makieła (red.), Studia KPZK PAN, t. CXXV, PAN Komitet Przestrzennego Zagospodarowania Kraju, Warszawa, s. 259-279.

3. Borowiec M., 2009, Rola edukacji w ksztaltowaniu spoleczeństwa informacyjnego [w:] Rola przedsiębiorczości w ksztaltowaniu społeczeństwa informacyjnego, Z. Zioło, T. Rachwał (red.), „Przedsiębiorczość - Edukacja”, nr 5, Nowa Era, Zakład Przedsiębiorczości i Gospodarki Przestrzennej Instytutu Geografii Uniwerystetu Pedagogicznego w Krakowie,Warszawa-Kraków, s. 37-47.

4. Domański B., 2001, Kapital zagraniczny w przemyśle Polski. Prawidłowości rozmieszczenia, uwarunkowania i skutki, Uniwersytet Jagielloński, Instytut Geografii i Gospodarki Przestrzennej, Kraków.

5. Gierańczyk W., Stańczyk A., 2003, Korporacje międzynarodowe w przestrzeni globalnej [w:] Ksztattowanie się struktur przemysłowych, Z. Zioło, Z. Makieła (red.), „Prace Komisji Geografii Przemysłu”, nr 5, Warszawa-Kraków, s. 73-84.

6. Kamińska W., 2006, Pozarolnicza indywidualna działalność gospodarcza w Polsce w latach 1988-2003, „Prace Geograficzne”, nr 203, IGiPZ PAN, Warszawa. 
7. Kamińska W., Heffner K. (red.), 2010, Kapitał ludzki i społeczny w procesie rozwoju obszarów wiejskich, Studia KPZK PAN, t. CXXVI, Warszawa.

8. Kilar W., 2009a, Korporacje informatyczne jako element struktury metropolii [w:] Potencjalne metropolie ze szczególnym uwzględnieniem Polski wschodniej, Z. Makieła (red.), Studia KPZK PAN, t. CXXV, PAN Komitet Przestrzennego Zagospodarowania Kraju, Warszawa, s. 136-153.

9. Kilar W., 2009, Rola korporacji Apple w ksztaltowaniu społeczeństwa informacyjnego [w:] Rola przedsiębiorczości $w$ kształtowaniu społeczeństwa informacyjnego, Z. Zioło, T. Rachwał (red.), „Przedsiębiorczość - Edukacja”, nr 5, Nowa Era, Zakład Przedsiębiorczości i Gospodarki Przestrzennej Instytutu Geografii Uniwerystetu Pedagogicznego w Krakowie, Warszawa-Kraków, s. 48-56.

10. Kitowski J., 2009, Influence of Global Economic Crisis on Operation of Special Economic Zones in Poland [w:] Countries if Central \& Eastern Europe Versus Global Economic Crisis, Polish Academy of Sciences, Institute of Geography and Spatial Organizations, J. Kitowski (ed.), „Geopolitical Studies”, vol. 15, Warsaw, 235-262.

11. Kudełko J., 2006, Efekty funkcjonowania specjalnych stref ekonomicznych w Polsce jako instrumentu polityki regionalnej. Prace z zakresu polityki ekonomicznej i programowania rozwoju, „Zeszyty Naukowe Akademii Ekonomicznej w Krakowie", nr 709, Kraków, s. 39-57.

12. Rachwał T., 2009, Rola przedsiębiorstw przemysłowych $w$ ksztaltowaniu obszarów metropolitalnych [w:] Potencjalne metropolie ze szczególnym uwzględnieniem Polski wschodniej, Z. Makieła (red.), Studia KPZK PAN, t. CXXV, PAN Komitet Przestrzennego Zagospodarowania Kraju, Warszawa, s. $121-135$.

13. Śleszyńki P., 2007, Gospodarcze funkcje kontrolne w przestrzeni Polski, „Prace Geograficzne”, nr 213, IGiPZ PAN, Warszawa.

14. Turczyn-Zioło I., 1979, Aspiracje i plany życiowe młodzieży szkót ponadpodstawowych obszaru uprzemysławianego i rolniczego (na przykładzie województwa tarnobrzeskiego), „Zeszyty Badań Rejonów Uprzemysławianych PAN”, z. 72.

15. Wajda E., 1963, Proces ksztaltowania się Motoroli jako firmy ponadnarodowej [w:] Ksztaltowanie się struktur przemystowych, Z. Zioło, Z. Makieła (red.), „Prace Komisji Geografii Przemysłu”, nr 5, Warszawa-Kraków, s. 85-114.

16. Zioło Z., 1978, Dochody ludności z pracy pozarolniczej [w:] Przemiany społeczno-ekonomiczne Tarnobrzeskiego Rejonu Uprzemysławianego, seria „Problemy Rejonów Uprzemysławianych”, PWN, Warszawa, s. 105-120.

17. Zioło Z., 1984, Wpływ polityki państwa na rozwój i przemiany struktury przestrzennej przemysłu (na przyktadzie Centralnego Okregu Przemystowego), „Folia Geographica. Series Geographica-Oeconomica", vol. XVII, s. 89-102.

18. Zioło Z., 1988, Funkcjonowanie i rozwój przedsiębiorstwa przemysłowego w przestrzeni geograficznej [w:] Zaktad przemystowy w akademickim kształceniu nauczycieli geografii, „Materiały i Sprawozdania", nr 16, Z. Zioło (red.), COMSN, Wyd. Nauk. WSP, Kraków, s. 8-24.

19. Zioło Z., Makieła Z. (red.), 2003, Przemyst w procesie globalizacji, „Prace Komisji Geografii Przemysłu PTG”, nr 6, Warszawa-Kraków.

20. Zioło Z., 2006, Zróżnicowanie światowej przestrzeni przemysłowej w świetle siedzib zarządów wiodacych korporacji [w:] Międzynarodowe uwarunkowania rozwoju polskiego przemystu, „Prace Komisji Geografii Przemysłu PTG”, nr 8, Warszawa-Kraków, s. 9-26.

21. Zioło Z., Rachwał T. (red.), 2005, Przedsiębiorczość a współczesne wyzwania cywilizacyjne, „Przedsiębiorczość - Edukacja”, nr 1, Wydawnictwo MiWa, Zakład Przedsiębiorczości i Gospodarki Przestrzennej Instytutu Geografii Akademii Pedagogicznej w Krakowie, Warszawa-Kraków.

22. Zioło Z., Rachwał T. (red.), 2006, Rola przedsiębiorczości w podnoszeniu konkurencyjności społeczeństwa i gospodarki, „Przedsiębiorczość - Edukacja”, nr 2, Nowa Era, Zakład Przedsiębiorczości i Gospodarki Przestrzennej Instytutu Geografii Akademii Pedagogicznej w Krakowie, Warszawa-Kraków. 
23. Zioło Z., Rachwał T. (red.), 2007, Rola przedsiębiorczości w aktywizacji gospodarczej-zarys mode$l u$, „Przedsiębiorczość - Edukacja”, nr 3, Nowa Era, Zakład Przedsiębiorczości i Gospodarki Przestrzennej Instytutu Geografii Akademii Pedagogicznej w Krakowie, Warszawa-Kraków.

24. Zioło Z., Rachwał T. (red.), 2008, Rola przedsiębiorczości w gospodarce opartej na wiedzy, „Przedsiębiorczość - Edukacja”, nr 4, Nowa Era, Zakład Przedsiębiorczości i Gospodarki Przestrzennej Instytutu Geografii Uniwerystetu Pedagogicznego w Krakowie, Warszawa-Kraków.

25. Zioło Z., Rachwał T. (red.), 2009, Rola przedsiębiorczości w ksztaltowaniu społeczeństwa informacyjnego, „Przedsiębiorczość - Edukacja”, nr 5, Nowa Era, Zakład Przedsiębiorczości i Gospodarki Przestrzennej Instytutu Geografii Uniwerystetu Pedagogicznego w Krakowie, Warszawa-Kraków.

26. Zioło Z., Rachwał T. (red.), 2010, Przedsiębiorczość w warunkach integracji europejskiej, „Przedsiębiorczość - Edukacja”, nr 6, Nowa Era, Zakład Przedsiębiorczości i Gospodarki Przestrzennej Instytutu Geografii Uniwerystetu Pedagogicznego w Krakowie, Warszawa-Kraków.

\section{The Role of Entrepreneurship in the Conditions of Intensifying Globalization Processes}

The paper presents the issues of role of entrepreneurship development in the conditions of intensifying globalization. Particular attention is paid to the impact of the rules of economic development, types of economic policies, the scale of spatial systems and types of businesses. Against this background, the paper discusses the functions and economic development of small businesses. 